\title{
Enterprise Risk Management For Fishing Tournaments
}

George Louis Hunt, Stephen F. Austin State University, USA

Jack R. Ethridge, Stephen F. Austin State University, USA

Violet C. Rogers, Stephen F. Austin State University, USA

\begin{abstract}
The fishing tournament industry is confronted with many of the same risks as other industries (such as financial statement misstatements), share some risks specific with others (such as cheating in casinos), and face some unique risks (such as the risk of competitors adding weight to fish).
\end{abstract}

This teaching case explores some of the risks inherent in the fishing tournament industry. Students are given background information about a how a tournament operates and then asked to perform an overall risk assessment using the COSO enterprise risk management framework. Elements of the assignment include assessing the internal environment, setting of objectives, and then identifying, prioritizing, and responding to risks. Students are also asked to make recommendations for improving the information and communications process and for improving monitoring activities.

The case contains the following elements:

- $\quad$ Case Narrative

- Instructors Manual

- Case Objectives

- Basic Pedagogy (course, level, position in the course, prerequisite knowledge)

- Teaching Methods

- Case Summary

- Key Issues

- Discussion questions and suggested responses

- $\quad$ Teaching Tips

- Instructor Tables

- Handouts

- Epilogue

The case is suited for use in several business courses at the undergraduate or graduate level. It can be used in part or in its entirety, and can be adjusted for difficulty levels. It is also adaptable to any of the major risk management models.

Keywords: ERM (Enterprise Risk Management Systems); internal controls; risk management; risk assessment; COSO; Teaching case

\section{INTRODUCTION}

66 wasn't trying to win. I just wanted to embarrass the tournament." Those were the words of Robby Rose, accused of adding a one-pound lead weight in the belly of a fish in order to win a fishing tournament and the prize of a $\$ 50,000$ boat. Rose is not alone in a growing number of fishermen who have been caught cheating in fishing tournaments. 


\section{BACKGROUND}

Fishing tournaments are a multi-billion dollar industry and the stakes at the events are high. It is not unusual to find cash and prizes for the winners exceeding $\$ 500,000$ in a single tournament. In one of the largest saltwater tournaments the winner stands to gain $\$ 1.2$ million.

With that amount of money at stake, there is plenty of incentive to win. Although fishing is generally believed to be a sport and not a game of chance, fishing tournaments have some of the same inherent risks as casinos and other gaming operations. There are significant amounts of money at stake and chance (or luck) plays a big part in determining the outcome. Under these conditions, some people will attempt to cheat.

The pioneer in bass fishing tournaments was Ray Scott. In the early 1960's he formed the Bass Anglers Sportsman Society (BASS) so bass fisherman could exchange information and promote their common interest. Scott also envisioned fishing tournaments as a profitable enterprise. His first tournament was held on Beaver Lake in northwest Arkansas in 1967. Within a few years the BASS had organized and promoted several hundred tournaments, and today there are thousands of tournaments held each year.

In the early days of Scott's BASS tournaments, there were no "professional" fishermen. Since then, the Bassmasters tournaments have expanded to include several classes of fisherman, from weekenders to full-time fishing professionals. The Weekend Series is designed for the non-professional fishermen, and will be the focus of the following description of a BASS fishing tournament. The following narrative was created by the authors to describe how the first tournament may have operated without the direction of Scott and his tournament rules.

\section{THE FIRST TOURNAMENT}

The Tournament was organized to allow competitors to enter the tournament by mailing or hand-carrying their applications and entry fees to the tournament director (TD) any time before the first day of fishing. The tournament was scheduled to include two eight-hour days with the boat with the heaviest catch over the two days declared the winner.

Each boat was to have two competitors who would act as team. Some registrants had a boat but others did not. Many of the registrants specified the boater and the rider as a team, but many of the registrants did not specify a rider. However, by the end of the registration period most registrants had found a partner, and those without partners were assigned one by the TD.

The night before fishing, several of the anglers got together and talked about the lake, the weather, and other topics of interest. A few questions came up, such as whether they could fish under a bridge that was being repaired at the time, and about the types of live bait that could be used. However, the TD could not be located that night.

At 7:00 a.m. the next morning, fishermen began loading their boats and checking their gas and engines. At 8:00 a.m. the boats left the dock to race to what the anglers believed to be the best spot for catching big fish. By the end of the eight hours most boats had arrived back to the weigh-in station, although a few straggled in later (the last boat in arrived 30 minutes late).

At the weigh-in station each boat could only present 8 fish: the heaviest 5 caught by the boat owner and the heaviest 3 fish caught by the rider. The fish were weighed and weights recorded on a large chalkboard at the weighin station. After recording their weights, the fish were returned to the anglers to dispose of as desired. Many anglers released their fish back into the lake, but some took their fish home to eat (since some of the fish were presented dead at the weigh-in).

The next morning the process was repeated. The results of day two were added to day one weights and the heaviest total weight won the tournament. 
Overall, the tournament was a great success. There were a few glitches, as could be expected, but no major problems had occurred. That was a great relief to the tournament director, who had feared boating accidents or a cheating scandal would kill the fledging enterprise. It was only several weeks later that the TD began hearing stories about what had allegedly occurred during the tournament. There were allegations that one angler had weighed in the same fish two days in a row. There were also stories of boats crowding each other out of the most sought after fishing spots, and boats arriving late to the weigh-in. There was also the issue of competitors being unsure of the tournament rules.

\section{EPILOGUE}

Robby Rose, introduced earlier, was convicted of theft by deceit and sentenced to 15 days in jail and five years probation. Stories like his are rare in Bassmaster tournaments because Ray Scott created a comprehensive set of rules designed to discourage and detect cheating before his first tournament. History has it that Scott was so concerned over the possibility of cheating that he locked himself in a motel room for several days and pounded out a set of rules to ensure that future tournaments were fraud-free. It is unclear what method Scott used in determining those rules, but he likely used many of the components found in the COSO framework. He knew that to be successful, he had to establish an environment with high ethical standards and free of misconduct. He also had to analyze the potential risks, prioritized those risks, and designed rules to combat those risks. He then had to communicate those rules and closely monitor future tournaments for violations.

Whatever method Scott used served his fishing tournaments well. The same set of rules he created for his first tournament is the basis of the modern day rules for all BASS tournaments. It is a tribute to his foresight in establishing strong controls over the tournament operations, because for almost 40 years there has yet to be major cheating scandal in a BASS tournament. They understand that without a strong system of internal controls tournament competitors and fans will be the ones who will be cheated in the end.

\section{DISCUSSION QUESTIONS}

1. How would you assess the internal environment of the tournament presented in the above scenario?

2. What are some of the strategic, operational, reporting, and compliance objectives that would be likely for a fishing tournament?

3. What are some of the possible events that may impede the reaching of the tournament objectives?

4. Using one of the methods of risk assessment, how would you rank the risks identified in question three?

5. What are your suggested risk responses to the high risks identifies in question four?

6. What control activities would you recommend for mitigating the risks?

7. What recommendations would you suggest to improve the information and communication processes?

8. What monitoring activities should the tournament consider?

\section{INSTRUCTORS MANUAL}

This teaching case explores some of the risk management issues surrounding fishing tournaments and the internal control activities used mitigate those risks. The COSO enterprise risk management framework is used to discuss and evaluate the risk management activities of a fishing tournament.

\section{Case Objectives}

The objective of the case is to have students gain experience in applying the COSO's enterprise risk management (ERM) framework.

\section{Basic Pedagogy}

Course: Internal auditing, auditing, fraud prevention, risk management, or general business courses.

Level: Designed for upper level undergraduate or graduate classes. 
Position in the course: Due to the flexibility in difficulty levels designed into the case, it could be used during any stage in the learning process (e.g., as an introduction to ERM or as a summary case).

Prerequisite knowledge: Familiarity with enterprise risk management.

The case can be modified to correspond with other risk management models, such as the CoCo or Turnbull models, depending on the predominate model used where the course is delivered.

\section{TEACHING METHODS}

The case is designed to introduce the students to the COSO ERM framework and its various components. Using the case narrative describing the operation of a fishing tournament, students are required to apply the COSO model to assess the internal environment, set objectives, and then identify, prioritize, and respond to risks. Students are also asked to make recommendations for improving information and communications process and for improving monitoring activities. This case focuses on a single tournament, a subunit of the bass fishing tournament circuit. Focusing on an operational subunit requires the student to consider objectives and risks not normally covered in an accounting class.

\section{CASE SUMMARY}

This case is designed to expose students to the COSO enterprise risk management (ERM) framework in the context of a fishing tournament. The assessment of the ERM activities is presented in the form an operating unit (a single tournament), part of a larger entity (tournament circuit). This exposes students to many risks and controls not normally encountered in other business settings.

The case begins with some background information about fishing tournaments, and then presents one possible scenario of how a fishing tournament may be operated. The tournament environment presented displayed weak control conditions and lackadaisical attitude concerning control issues, resulting in significant weaknesses in internal controls.

Students are asked to evaluate the internal environment of the fishing scenario using the COSO enterprise risk management (ERM) framework, then determine possible objectives in the four areas of the ERM model (strategic, operations, reporting, and compliance). Additional requirements include completion of an event identification analysis, conducting a risk assessment, and determining risk responses, including appropriate control activities. Students complete the requirements by providing recommendations for improvements to the information and communications processes and suggestions for improving the monitoring process.

The business of fishing tournaments shares many of the risks of other business models, and also has exposure to some rather unique risks. This case provides an example of using the important components of the COSO risk management model to evaluate risk management activities of a fishing tournament.

Key Issues (for a single fishing tournament):

1. Assessment of the internal environment

2. Setting of strategic, operational, reporting, and compliance objectives

3. Identification of potential risks

4. Conducting a risk assessment

5. Determination of appropriate risk responses

6. Design of effective control activities

7. Evaluating information and communications processes

8. Recommending appropriate monitoring activities 


\section{SUGGESTED RESPONSES}

1. How would you assess the internal environment of the tournament presented in the above scenario?

Required: Assessment of internal environment

[COSO Summary: The internal environment encompasses the tone of an organization, and sets the basis for how risk is viewed and addressed by an entity's people, including risk management philosophy and risk appetite, integrity and ethical values, and the environment in which they operate.]

Likely assessment:

The scenario presented in the case appears to have a weak control environment. Governance was almost absent and operations were exposed to several weaknesses in internal control.

Areas of weakness in the control environment:

- $\quad$ Lack of apparent established line of authority and responsibilities

- $\quad$ Numerous opportunities for cheating by competitors

- $\quad$ Poor communications between the TD, other tournament staff, and competitors

- $\quad$ General attitude about rule compliance

- $\quad$ Poorly controlled registration process

- $\quad$ Little regard for safety, integrity, or rules.

Teaching Note: Senior management of Bassmaster tournaments, and Scott in particular, were extremely concerned about the possibility of cheating scandals in the tournaments. He continually strengthened the rules to decrease the possibility of cheating. Publicity surrounding cheating and adherence to the rules were plainly and conspicuous in the official rules and on the application to fish. He had no tolerance for infractions and resulted in legal action being taken. The internal environment he established was conducive to effective risk management activities.

2. What are some of the strategic, operational, reporting, and compliance objectives that would be likely for a fishing tournament?

[COSO Summary: Objective Setting - Objectives must exist before management can identify potential events affecting their achievement. Enterprise risk management ensures that management has in place a process to set objectives and that the chosen objectives support and align with the entity's mission and are consistent with its risk appetite.]

Teaching note: Students often have difficulty understanding the differences and interdependencies of the four major objectives of an organization (strategic, operational, reporting, and compliance). Especially troublesome is setting objectives at the entity level versus the Process or Subunit level. Listed below are likely responses for strategic objectives at the entity level (tournament circuit) and strategic objectives at the operating level (a single tournament) assuming the single tournament is part of tournament circuit.

Likely objectives:

Strategic objectives (Entity level):

- Increase number of tournaments

- Increase attendance at tournaments

- Increase number of competitors

- $\quad$ Achieve and maintain profitability 
- $\quad$ Establish/maintain a social responsibility environmental public image

- $\quad$ Expand the "BASS" brand recognition

- $\quad$ Attract sponsorships and vendor participation

- $\quad$ Promote the sport of bass fishing

- $\quad$ Avoid legal liabilities

Strategic objectives (Subunit level - a single tournament):

- $\quad$ Achieve a minimum of 100 spectators

- $\quad$ Recruit 20 to 40 competitors

- Achieve a profit of $15 \%$

- Demonstrate social responsibility

- Expose the attendees to the "BASS" brand

- Maintain a drug/alcohol free environment

Operational objectives (Subunit level - a single tournament):

- $\quad$ Conduct a fair competition

- $\quad$ Eliminate boating accidents

- $\quad$ Ensure cash and prizes are sufficient to attract competitors

- $\quad$ Act in a socially responsible manner

- $\quad$ Competitors having a good experience

- $\quad$ Competitors conforming to eligibility requirements

Reporting objectives:

- $\quad$ Provide reliable and timely financial statements and operational information

- $\quad$ Report contest results accurately and timely

- $\quad$ Effectively disseminate tournament rules

- $\quad$ Provide accurate and timely information to regulatory agencies

Compliance objectives:

Comply with:

- $\quad$ State and federal gaming laws

- $\quad$ Taxing authority regulations

- $\quad$ IRS tax requirements

- $\quad$ State fishing regulations

- $\quad$ FCC rules (if broadcast)

- $\quad$ Activist organizations (e.g., PETA) demands

- $\quad$ Other environmental issues

3. What are some of the possible events that may impede the reaching of the tournament objectives?

Required: Event identification analyses

[COSO Summary: Event Identification - Internal and external events affecting achievement of an entity's objectives must be identified, distinguishing between risks and opportunities. Opportunities are channeled back to management's strategy or objective-setting processes.]

Likely events: 
Risks to Strategic objectives (single tournament)

- $\quad$ Poor attendance from competitors due to insufficient prizes

- $\quad$ Lack of publicity for tournament/gathering sufficient spectator interest

- $\quad$ Expenses exceeding revenues

- $\quad$ Competitors being under the influence of drugs or alcohol

- $\quad$ Bad publicity for not being environmentally friendly

Risks to Operational objectives:

- $\quad$ Cheating or other misconduct by competitors or spectators

- $\quad$ Problems with registration of competitors or other administrative tasks

- $\quad$ Inclement weather or poor fishing conditions (e.g., muddy water, red tide, overcrowding)

- $\quad$ Equipment inaccuracies or malfunction

- $\quad$ Failure of staff to properly carry out responsibilities

- Weak administration of tournament and/or incompetent/corrupt tournament director

- $\quad$ Advance knowledge of the tournament venue

- $\quad$ Boating accidents

- $\quad$ Competitors having an unpleasant experience

Risks to Reporting objectives:

- Inaccurate reporting to state wildlife authorities

- Inaccurate tax reporting of winners and the promoters

- Inaccurate announcements/communications at the tournament

- $\quad$ Failure to provide appropriate financial statements or other internal reporting

Risks to Compliance objectives:

- $\quad$ Noncompliance with State and federal gaming laws/regulations

- Improper reporting to the IRS and state taxing authorities on winners' boot

- $\quad$ Disregard for demands from activist organizations (e.g., PETA)

- $\quad$ Insensitivity to other environmental issues

4. Using one of the methods of risk assessment, how would you rank the risks identified in question three?

[COSO Summary: Risk Assessment - Risks are analyzed, considering likelihood and impact, as a basis for determining how they should be managed. Risks are assessed on an inherent and a residual basis.]

Possible risk assessments: See completed risk matrix in the appendix

5. What are your suggested risk responses to the high risks identifies in question four?

[COSO Summary: Risk Response - Management selects risk responses - avoiding, accepting, reducing, or sharing risk - developing a set of actions to align risks with the entity's risk tolerances and risk appetite.]

Possible Risk Reponses: See completed risk matrix in the appendix

6. What control activities would you recommend for mitigating the risks?

Required: Development of appropriate control activities 
[COSO Summary: Control Activities - Policies and procedures are established and implemented to help ensure the risk responses are effectively carried out.]

Possible control activities: See completed risk matrix in the appendix

Other possible control activities for operational risks include:

- $\quad$ Eliminate cheating or other misconduct by competitors or spectators by

$\circ \quad$ communicating and enforcing a comprehensive set of rules

$\circ \quad$ monitoring of competitors by tournament officials

$\circ \quad$ require two competitors per boat, which are unrelated and randomly assigned to boats by tournament officials

- requiring a pre-fishing meeting to review the rules, indicate where fishing is/is not allowed

$\circ \quad$ maintain accurate and timely records of competitors guilty of engaging in inappropriate behavior and sanctions imposed

$\circ \quad$ visibility of such records to the competitors and tournament staff

$\circ \quad$ use radio and other electronic communications scanners to detect disallowed communications between competitors or other accomplices

$\circ \quad$ having anonymous officials monitoring boating and fishing practices during the tournament

$\circ \quad$ establishing an effective hotline for reporting violations to rules

- limit means of securing fish to the traditional line and hook (no netting or other fishing methods)

$\circ \quad$ posting of rules at conspicuous locations

- $\quad$ Neutralize any advantage gained by advanced knowledge of the tournament venue by (1) holding the tournament in a secret location, (2) allowing appropriate time for all competitors to practice on the lake prior to the tournament

- Minimize the effects of inclement weather by: (1) holding the tournament on dates known or thought to be generally favorable for fishing, (2) having criteria established to determine if the weather is "inclement," (3) having a pre-determined date if weather causes cancellation, (4) communicating the alternatives to all competitors

- $\quad$ Minimize the impact of equipment inaccuracies or malfunction by: (1) have weigh-in scales tested and verified for accuracy by competent professional, (2) maintain back-up equipment for key items

- $\quad$ Reduce probability of failure of staff to carry out responsibilities by: (1) the TD should be conspicuous and readily available, with a designated alternative TD if necessary, (2) maintain proper segregation of duties, (3) Employing a well trained staff

- Strong administration of tournament by: (1) having policies and procedures for each facet of the tournament, (2) strict rules and controls to limit access to results board and other reporting or operational areas

- Incompetent/Corrupt tournament director: (1) Perform a background check as part of hiring process, (2) purchase a fidelity bond to cover malfeasance or other corrupt acts, (3) Subject TD to polygraph in cases where he is accused of inappropriate acts, (4) provide adequate training in rules, (5) require affirmative statement of compliance with rules, (6) require disclosure of any conflicts of interest

- $\quad$ Eliminate boating accidents by: (1) requiring boaters to complete a boating safety training, (2) requiring each boat to have certain safety equipment on board, (3) requiring boaters to carry accident insurance, (4) requiring boaters to sign an affirmative statement concerning conformity with safety rules, (5) conducting random inspection of boats and equipment for compliance with safety requirements, (6) Placing limits on engine horsepower, (7) have tournament boats patrolling for infractions to safety rules

- $\quad$ Minimize legal liability arising from competitor actions by: (1) require competitors to sign a release from liability statement

- Maximize competitors satisfaction with the experience by: (1) conducting a fair contest, (2) applying the rules uniformly to all competitors, (3) provide a hospitable environment for participants and spectators

- $\quad$ Formalize registration of competitors by: (1) requiring registration forms and payments timely enough to validate information, (2) use of standardized forms, (3) separate duties of operating the tournament from 
registration and related administrative tasks

- $\quad$ Ensure all competitors conform to eligibility requirements by: (1) clearly communicating the eligibility requirements, (2) validating registration data with other sources (e.g., state birth certificate records and BASS membership data), (3) having badge visible for entrance into boating area or fishing areas

- $\quad$ Reduce impact of accidents/injuries by (1) have medical personnel on site in case of accidents resulting in injuries, (2) maintain insurance coverage, (3) require release of liability statement

- Minimize "down-time" from equipment malfunction by (1) having back-up equipment, (2) performing proper preventive maintenance, (3) conducting periodic inspections

- To prevent tournament officials cheating or in collusion with others there should be proper segregation of duties among registration process, fishing operations, weigh-in staff, and other officials.

7. What recommendations would you suggest to improve the information and communication processes?

Required: Provide recommendations to improve the information and communication processes

[COSO Summary: Information and Communication - Relevant information is identified, captured, and communicated in a form and timeframe that enable people to carry out their responsibilities. Effective communication also occurs in a broader sense, flowing down, across, and up the entity.]

Possible recommendations for improving the information and communications process:

1. Readily available documentation of participants (valid fisherman list)

2. Tracking competitors for rule infractions

3. Mandating a pre-fishing briefing where pertinent information is disseminated to participants

4. Permanent recording of all weighs-ins in adequate details to facilitate subsequent analyses and for archival purposes

5. Provide all officials with compatible communication devices (radios, walkie-talkies, cell phones)

6. Ability to immediately lodge a complaint to any tournament official

8. What activities should the tournament consider instituting to strengthen the monitoring process?

[COSO Summary: Monitoring - The entirety of enterprise risk management is monitored and modifications made as necessary. Monitoring is accomplished through ongoing management activities, separate evaluations, or both.]

Possible monitoring activities:

- Survey of participants at conclusion of tournament

- $\quad$ Collection of anecdotal evidence of attendees experience by official's inquiry

- $\quad$ Review of documentation of eligibility requirements, insurance coverage, etc.

- $\quad$ Competitors should be continually observed (covert and overt) by tournament officials

- $\quad$ Solicitation of infractions observed by spectators

- $\quad$ Updating of rules when a new cheating scheme emerges

- $\quad$ Engage risk management experts to review ERM processes

Teaching tips and interesting facts:

There are over 32,000 fishing tournaments in the North America alone (Schramm and Hunt, 2007).

In the Ahrens v. McDaniel case, the tournament director disqualified the fish because it had ice in its stomach, and the courts upheld the TD's right to do so. (Icing fish down is permitted in some saltwater tournaments, so the presence of ice itself was not compelling evidence.) This result was particularly unfortunate for the 
fishermen, because the weight of the fish without the ice was still far more than any other caught that day.

Polygraphs typically used in tournament testing costs between $\$ 150$ - $\$ 600$ (Tolliver, August 17, 2010).

Polygraphs can be beaten, as evidenced in the Lidz story. After an investigation of substituting a Florida bass for the local species, a $\$ 105,000$ prize-winning angler confessed to the fraud. He claims to have beaten the polygraph test administered the day of the weigh-in by taking Valium.

In the same story, Lidz recounts a tale of a fisherman boarding his boat the morning of a tournament wearing a full length raincoat, even though it was a sunny day. On investigation by tournament officials, he was found to have a stringer of fish ready to dump into the live-well.

For the first few years of promoting the Championship Tournaments, Scott would load all the competitors (there were 24 in the first year) into an airplane and fly to the secret destination to hold the tournament, and each competitor was to have exactly the same boat. Because of a major fire that year at the boat builder's (Ranger Boats) factory, Scott was not able to use identical boats. But over the years as the contest became so popular with the fans he had to let the location be known in advance so spectators and the media could attend.

\title{
Instructor Tables
}

See completed control matrix and risk maps in the appendix

\author{
Handouts \\ Abbreviated tournament rules \\ Risk Map \\ Risk Matrix
}

\section{CONCLUSION}

The Fishing Tournament Case requires students to identify risks at various levels and incorporate them into the COSO model. Students are required to assess the internal environment and identify strategic, operational, reporting, and compliance objectives that would be likely for a fishing tournament. In addition, students will be asked to identify controls that would mitigate the identified risks. The case is helpful in helping the student to understand the integration of risks and controls. Teaching notes and suggestions are included. 


\section{Appendix}

\section{Abbreviated Tournament Rules}

The Tournament Director or his designee has the final authority on interpretation and enforcement of the following rules:

1. Participants must meet eligibility requirements:

- $\quad$ Minimum age of 16

- Member of BASS

- Maintain minimum of $\$ 300,000$ per incident of boating liability insurance

- $\quad$ Properly completed entry forms with entry fees

2. Competitors must comply with an angler code of conduct, which includes restrictions on media comments or public attacks on judges or rules, with sanctions for infractions

3. Competitors are restricted from certain activities during competition, with sanctions for infractions:

- An angler may get assistance or advice in locating fish from one other competitor

- A competitor may not skin dive or scuba dive

- A competitor may not buy or barter for a fishing location

- $\quad$ Competitors may not use electronic communication devices (e.g., 2-way radios or cell phones) except in an emergency

- $\quad$ Tournament officials may not be denied access to any competitors boat at any time

- $\quad$ Each competitor must agree to report infractions of the rules to tournament officials

- $\quad$ Each competitor must agree to take a polygraph test at the discretion of the Tournament Director

4. Competitors must attend a pre-tournament briefing, where rules are reviewed and other administrative tasks are performed

5. Competitors must abide by safety rules

- $\quad$ Safe boating practices

- Delays for inclement weather

- $\quad$ Obey speed limits, if any

- $\quad$ Competitors may leave their boat for safety reasons (see associated rule below)

6. Competitors must display good sportsmanship

- No alcohol or drug use

- Maximum courtesy to others

- Obey local/state statutes and regulations

- Applications to compete may be rejected for drug addiction, felony convictions, etc.

7. Tackle and equipment that may be used are restricted:

- $\quad$ Use of 'grippers' are prohibited (long-handled pliers)

- $\quad$ Live or prepared baits are prohibited

- Only one rod ( 8 ' maximum) and reel may be used at a time (although the number of rods and reels in the boat is unrestricted)

- $\quad$ Fish must be caught live and in the conventional manner (hooked in the mouth) and may not be caught by snagging or snatching

8. Restrictions on the boats and motors

- $\quad$ Maximum horsepower limits

- $\quad$ requirements for safety features on board

- $\quad$ legal registration requirements

- $\quad$ each boat/motor will be inspected by tournaments officials at the start of each day

- $\quad$ each boat is assigned a number for identification by tournament officials

- $\quad$ observers may be assigned to boats

9. Competitors may only fish in designated areas and only during tournament hours

10. Competitors must remain in the boat (except in emergencies) during the tournament hours

11. Competitors must check in at the designated location at the appointed time with assigned number and proceed directly to a 
secure weigh-in area

12. Scoring is as follows:

- $\quad$ Scored on pounds and ounces of the largest five fish caught

- $\quad$ Fish must be alive and within the minimum and maximum lengths (weight reduction penalties are assessed for fish outside the limits or for dead fish)

- $\quad$ A one pound per minute penalty is assed if a competitor is late to check-in

- $\quad$ Maximum of 5 specified species of fish (e.g., largemouth bass) are permitted

13. Taxes are withheld for prize winnings

14. Competitors must sign a waiver and release of liability form holding the tournament harmless in case of an accident

The above rules were condensed and modified from the official rules attached in the appendix. To view the complete rules, application, release of liability waivers and other documents go online to:

http://sports.espn.go.com/outdoors/bassmaster/bmseries/news/story?page=b_news_weekend_rules_04 


\section{Risk Map}

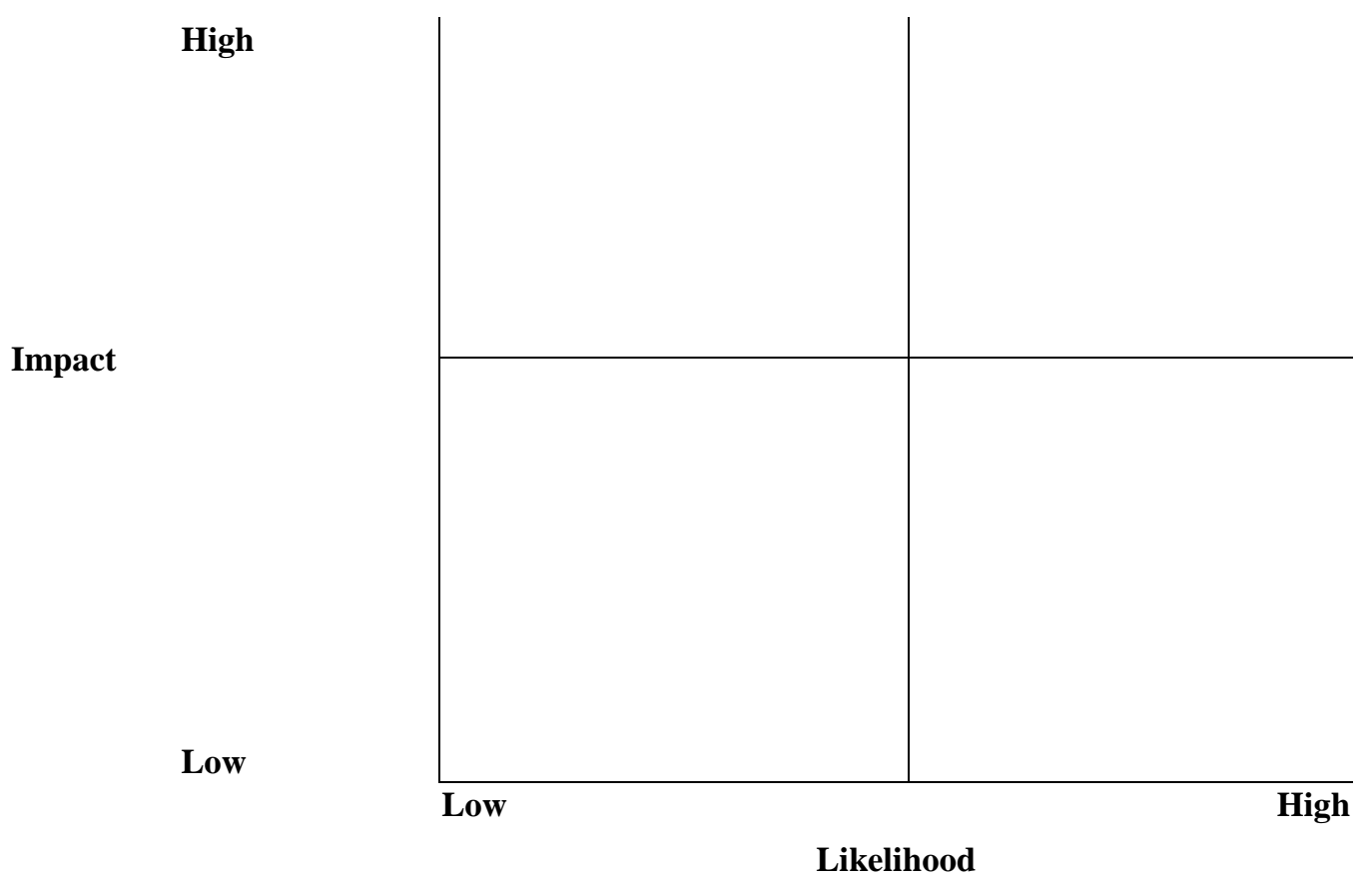




\begin{tabular}{|c|c|c|c|c|c|c|c|}
\hline \multicolumn{8}{|c|}{ Risk/Control Matrix } \\
\hline $\begin{array}{c}\text { Activity } \\
\text { within Key } \\
\text { Process }\end{array}$ & $\begin{array}{c}\text { Risk } \\
\text { Statement }\end{array}$ & $\begin{array}{l}\text { Impact } \\
\text { Rating }\end{array}$ & $\begin{array}{l}\text { Likelihood } \\
\text { Rating }\end{array}$ & Ranking & $\begin{array}{c}\text { Risk } \\
\text { Response }\end{array}$ & $\begin{array}{l}\text { Control } \\
\text { Activity }\end{array}$ & $\begin{array}{l}\text { Technique for } \\
\text { Assessing } \\
\text { Effectiveness }\end{array}$ \\
\hline & & & & & & & \\
\hline & & & & & & & \\
\hline & & & & & & & \\
\hline & & & & & & & \\
\hline & & & & & & & \\
\hline & & & & & & & \\
\hline & & & & & & & \\
\hline & & & & & & & \\
\hline & & & & & & & \\
\hline & & & & & & & \\
\hline & & & & & & & \\
\hline & & & & & & & \\
\hline & & & & & & & \\
\hline
\end{tabular}




\begin{tabular}{|c|c|c|c|c|c|c|c|}
\hline \multicolumn{8}{|c|}{ Risk/Control Matrix } \\
\hline $\begin{array}{l}\text { Activity within } \\
\text { Key Process }\end{array}$ & Risk Statement & $\mid \begin{array}{l}\text { Impact } \\
\text { Rating }\end{array}$ & $\begin{array}{c}\text { Likelihood } \\
\text { Rating }\end{array}$ & Ranking & $\begin{array}{c}\text { Risk } \\
\text { Response }\end{array}$ & $\begin{array}{l}\text { Control } \\
\text { Activity }\end{array}$ & $\begin{array}{l}\text { Technique for } \\
\text { Assessing } \\
\text { Effectiveness }\end{array}$ \\
\hline \multicolumn{8}{|l|}{ Strategic } \\
\hline $\begin{array}{l}\text { Environmentally } \\
\text { friendly }\end{array}$ & $\begin{array}{l}\text { Competitors not } \\
\text { acting in a socially } \\
\text { responsible manner } \\
\text { may threaten } \\
\text { objectives of future } \\
\text { tournaments }\end{array}$ & High & High & 1 & Reduce & $\begin{array}{l}\text { Operate under } \\
\text { catch and } \\
\text { release } \\
\text { philosophy; } \\
\text { penalty for } \\
\text { dead fish; } \\
\text { donate dead } \\
\text { fish to local } \\
\text { charity; require } \\
\text { adherence to } \\
\text { sportsman code } \\
\text { of conduct } \\
\end{array}$ & $\begin{array}{l}\text { Monitor media for } \\
\text { bad publicity }\end{array}$ \\
\hline $\begin{array}{l}\text { Competitor } \\
\text { attendance }\end{array}$ & $\begin{array}{l}\text { Poor attendance from } \\
\text { competitors due to } \\
\text { insufficient prizes }\end{array}$ & High & Medium & 2 & Reduce & $\begin{array}{l}\text { Establish } \\
\text { minimum cash } \\
\text { and prize } \\
\text { amounts }\end{array}$ & $\begin{array}{l}\text { Compare actual } \\
\text { attendance with } \\
\text { planned/break-even } \\
\text { attendance }\end{array}$ \\
\hline $\mid \begin{array}{l}\text { Spectator } \\
\text { attendance }\end{array}$ & $\begin{array}{l}\text { Lack of publicity for } \\
\text { tournament and/or } \\
\text { insufficient spectator } \\
\text { interest }\end{array}$ & High & Medium & 3 & Reduce & $\begin{array}{l}\text { Provide } \\
\text { adequate } \\
\text { publicity for } \\
\text { tournament }\end{array}$ & $\begin{array}{l}\text { Compare actual } \\
\text { attendance with } \\
\text { planned/break-even } \\
\text { attendance }\end{array}$ \\
\hline $\begin{array}{l}\text { Expenses } \\
\text { exceeding } \\
\text { revenues }\end{array}$ & $\begin{array}{l}\text { Expenses exceeding } \\
\text { revenues would } \\
\text { create an operating } \\
\text { loss }\end{array}$ & Medium & Medium & 4 & Reduce & $\begin{array}{l}\text { Prepare and } \\
\text { monitor } \\
\text { budgets }\end{array}$ & Budgetary analyses \\
\hline Drugs or alcohol & $\begin{array}{l}\text { Competitors under } \\
\text { the influence may } \\
\text { create unsafe boating } \\
\text { condition, bring bad } \\
\text { publicity, or invite } \\
\text { other misconduct }\end{array}$ & High & Low & 5 & Reduce & $\begin{array}{l}\text { Random drug } \\
\text { testing; } \\
\text { disqualification } \\
\text { for violation }\end{array}$ & $\begin{array}{l}\text { Monitor number of } \\
\text { cases of drug or } \\
\text { alcohol use }\end{array}$ \\
\hline Operational & & & & & & & \\
\hline
\end{tabular}




\begin{tabular}{|c|c|c|c|c|c|c|c|}
\hline Misconduct & $\begin{array}{l}\text { Cheating or other } \\
\text { misconduct by } \\
\text { competitors or } \\
\text { spectators }\end{array}$ & High & High & 1 & Reduce & \begin{tabular}{|l|} 
Establish \\
comprehensive \\
rules with strict \\
enforcement \\
and sanctions \\
for violations; \\
mechanism for \\
reporting \\
violations; \\
close \\
monitoring of \\
competitors by \\
tournament \\
officials; \\
require \\
polygraph \\
testing
\end{tabular} & $\begin{array}{l}\text { Monitor hotlines } \\
\text { and other sources } \\
\text { for infractions }\end{array}$ \\
\hline Accidents & $\begin{array}{l}\text { Boating or other } \\
\text { accidents could } \\
\text { reflect badly on } \\
\text { tournament }\end{array}$ & High & Medium & 2 & Transfer & \begin{tabular}{|l|} 
Require boating \\
safety class; \\
mandate \\
boating \\
insurance; \\
require \\
adherence to \\
sportsman code \\
of conduct; \\
release of \\
liability \\
statement
\end{tabular} & $\begin{array}{l}\text { Monitor number } \\
\text { and severity of } \\
\text { boating accidents }\end{array}$ \\
\hline Registration & $\begin{array}{l}\text { Problems with } \\
\text { registration of } \\
\text { competitors or other } \\
\text { administrative tasks }\end{array}$ & Medium & High & 3 & Control & $\begin{array}{l}\text { Establish } \\
\text { policies and } \\
\text { procedures }\end{array}$ & $\begin{array}{l}\text { Monitor complaints } \\
\text { from competitors } \\
\text { and others }\end{array}$ \\
\hline $\begin{array}{l}\text { Competitor } \\
\text { satisfaction }\end{array}$ & $\begin{array}{l}\text { Competitors having } \\
\text { an unpleasant } \\
\text { experience }\end{array}$ & Medium & Medium & 4 & Reduce & \begin{tabular}{|l|} 
Develop and \\
administer \\
survey of \\
competitors for \\
satisfaction; \\
adjust \\
operations as \\
necessary
\end{tabular} & $\begin{array}{l}\text { Monitor survey } \\
\text { results }\end{array}$ \\
\hline $\begin{array}{l}\text { Equipment } \\
\text { malfunction }\end{array}$ & $\begin{array}{l}\text { Equipment } \\
\text { inaccuracies or } \\
\text { malfunction }\end{array}$ & Medium & Medium & 5 & Reduce & \begin{tabular}{|l|} 
Conduct \\
periodic \\
inspections; \\
perform routine \\
maintenance; \\
maintain back- \\
up for critical \\
equipment
\end{tabular} & $\begin{array}{l}\text { Monitor operations } \\
\text { for frequency of } \\
\text { equipment } \\
\text { malfunction }\end{array}$ \\
\hline
\end{tabular}




\begin{tabular}{|c|c|c|c|c|c|c|c|}
\hline Administration & $\begin{array}{l}\text { Failure of staff to } \\
\text { properly carry out } \\
\text { responsibilities ; } \\
\text { Weak administration } \\
\text { of tournament and/or } \\
\text { incompetent/corrupt } \\
\text { tournament director }\end{array}$ & Medium & Low & 6 & Reduce & $\begin{array}{l}\text { Hire competent } \\
\text { staff; complete } \\
\text { background } \\
\text { checks; } \\
\text { purchase } \\
\text { fidelity bonds }\end{array}$ & $\begin{array}{l}\text { Review satisfaction } \\
\text { survey for } \\
\text { administrative tasks }\end{array}$ \\
\hline Weather & $\begin{array}{l}\text { Inclement weather or } \\
\text { poor fishing } \\
\text { conditions (e.g., } \\
\text { muddy water, red } \\
\text { tide, overcrowding) }\end{array}$ & Medium & Low & 7 & Accept & $\begin{array}{l}\text { Prepare } \\
\text { contingency } \\
\text { plans for delay } \\
\text { or reschedule } \\
\text { dates }\end{array}$ & $\begin{array}{l}\text { Monitor frequency } \\
\text { of } \\
\text { delays/rescheduling }\end{array}$ \\
\hline \multicolumn{8}{|l|}{ Reporting } \\
\hline IRS reporting & $\begin{array}{l}\text { Inadequate/inaccurate } \\
\text { reporting }\end{array}$ & High & Medium & 1 & Reduce & $\begin{array}{l}\text { Hire and train } \\
\text { competent } \\
\text { administrative } \\
\text { staff; require } \\
\text { IRS } \\
\text { identification } \\
\text { numbers on } \\
\text { application }\end{array}$ & $\begin{array}{l}\text { Monitor } \\
\text { correspondence; } \\
\text { management } \\
\text { review of filings } \\
\text { and reporting }\end{array}$ \\
\hline $\begin{array}{l}\text { Financial } \\
\text { reporting }\end{array}$ & $\begin{array}{l}\text { Inadequate/inaccurate } \\
\text { reporting }\end{array}$ & Medium & Medium & 2 & Reduce & $\begin{array}{l}\text { Hire and train } \\
\text { competent } \\
\text { administrative } \\
\text { staff; establish } \\
\text { policies and } \\
\text { procedures for } \\
\text { reporting }\end{array}$ & $\begin{array}{l}\text { Monitor } \\
\text { correspondence; } \\
\text { management } \\
\text { review of filings } \\
\text { and reporting }\end{array}$ \\
\hline $\begin{array}{l}\text { Gaming } \\
\text { Commission }\end{array}$ & $\begin{array}{l}\text { Inadequate/inaccurate } \\
\text { reporting }\end{array}$ & High & Low & 3 & Reduce & $\begin{array}{l}\text { Hire and train } \\
\text { competent } \\
\text { administrative } \\
\text { staff; establish } \\
\text { policies and } \\
\text { procedures for } \\
\text { reporting }\end{array}$ & $\begin{array}{l}\text { Monitor } \\
\text { correspondence; } \\
\text { management } \\
\text { review of filings } \\
\text { and reporting }\end{array}$ \\
\hline $\begin{array}{l}\text { State wildlife } \\
\text { authorities }\end{array}$ & $\begin{array}{l}\text { Inadequate/inaccurate } \\
\text { reporting }\end{array}$ & High & Low & 4 & Reduce & $\begin{array}{l}\text { Hire and train } \\
\text { competent } \\
\text { administrative } \\
\text { staff; establish } \\
\text { policies and } \\
\text { procedures for } \\
\text { reporting }\end{array}$ & $\begin{array}{l}\text { Monitor } \\
\text { correspondence; } \\
\text { management } \\
\text { review of filings } \\
\text { and reporting }\end{array}$ \\
\hline $\begin{array}{l}\text { Announcements } \\
\text { and } \\
\text { communications }\end{array}$ & $\begin{array}{l}\text { Inadequate/inaccurate } \\
\text { reporting }\end{array}$ & Medium & Low & 5 & Reduce & $\begin{array}{l}\text { Hire and train } \\
\text { competent } \\
\text { administrative } \\
\text { staff; establish } \\
\text { policies and } \\
\text { procedures for } \\
\text { reporting }\end{array}$ & $\begin{array}{l}\text { Monitor } \\
\text { correspondence; } \\
\text { management } \\
\text { review of filings } \\
\text { and reporting }\end{array}$ \\
\hline Compliance & & & & & & & \\
\hline
\end{tabular}




\begin{tabular}{|c|c|c|c|c|c|c|c|}
\hline $\begin{array}{l}\text { Gaming } \\
\text { laws/regulations }\end{array}$ & $\begin{array}{l}\text { Noncompliance with } \\
\text { reporting } \\
\text { requirements }\end{array}$ & High & Medium & 1 & Reduce & $\begin{array}{l}\text { Hire and train } \\
\text { competent } \\
\text { administrative } \\
\text { staff; establish } \\
\text { policies and } \\
\text { procedures for } \\
\text { reporting }\end{array}$ & $\begin{array}{l}\text { Monitor frequency } \\
\text { of violations to } \\
\text { gaming regulations }\end{array}$ \\
\hline IRS & $\begin{array}{l}\text { Improper reporting to } \\
\text { the IRS and state } \\
\text { taxing authorities on } \\
\text { winners' boot }\end{array}$ & High & Medium & 2 & Reduce & $\begin{array}{l}\text { Hire and train } \\
\text { competent } \\
\text { administrative } \\
\text { staff; establish } \\
\text { policies and } \\
\text { procedures for } \\
\text { reporting }\end{array}$ & $\begin{array}{l}\text { Monitor frequency } \\
\text { of improper } \\
\text { reporting; hire } \\
\text { competent staff }\end{array}$ \\
\hline $\begin{array}{l}\text { Activist } \\
\text { organizations }\end{array}$ & $\begin{array}{l}\text { Disregard for } \\
\text { demands from activist } \\
\text { organizations }\end{array}$ & Medium & Medium & 3 & Reduce & $\begin{array}{l}\text { Hire and train } \\
\text { competent } \\
\text { administrative } \\
\text { staff; establish } \\
\text { policies and } \\
\text { procedures for } \\
\text { reporting }\end{array}$ & $\begin{array}{l}\text { Monitor } \\
\text { correspondence } \\
\text { from activist } \\
\text { organizations; } \\
\text { monitor operations } \\
\text { for compliance }\end{array}$ \\
\hline $\begin{array}{l}\text { Other } \\
\text { environmental } \\
\text { issues }\end{array}$ & $\begin{array}{l}\text { Insensitivity to other } \\
\text { environmental issues } \\
\text { could create bad } \\
\text { publicity }\end{array}$ & Medium & Low & 4 & Accept & $\begin{array}{l}\text { Hire and train } \\
\text { competent } \\
\text { administrative } \\
\text { staff; establish } \\
\text { policies and } \\
\text { procedures for } \\
\text { reporting }\end{array}$ & $\begin{array}{l}\text { Monitor operations } \\
\text { for environment } \\
\text { issues }\end{array}$ \\
\hline
\end{tabular}




\section{Strategic Risk Map}

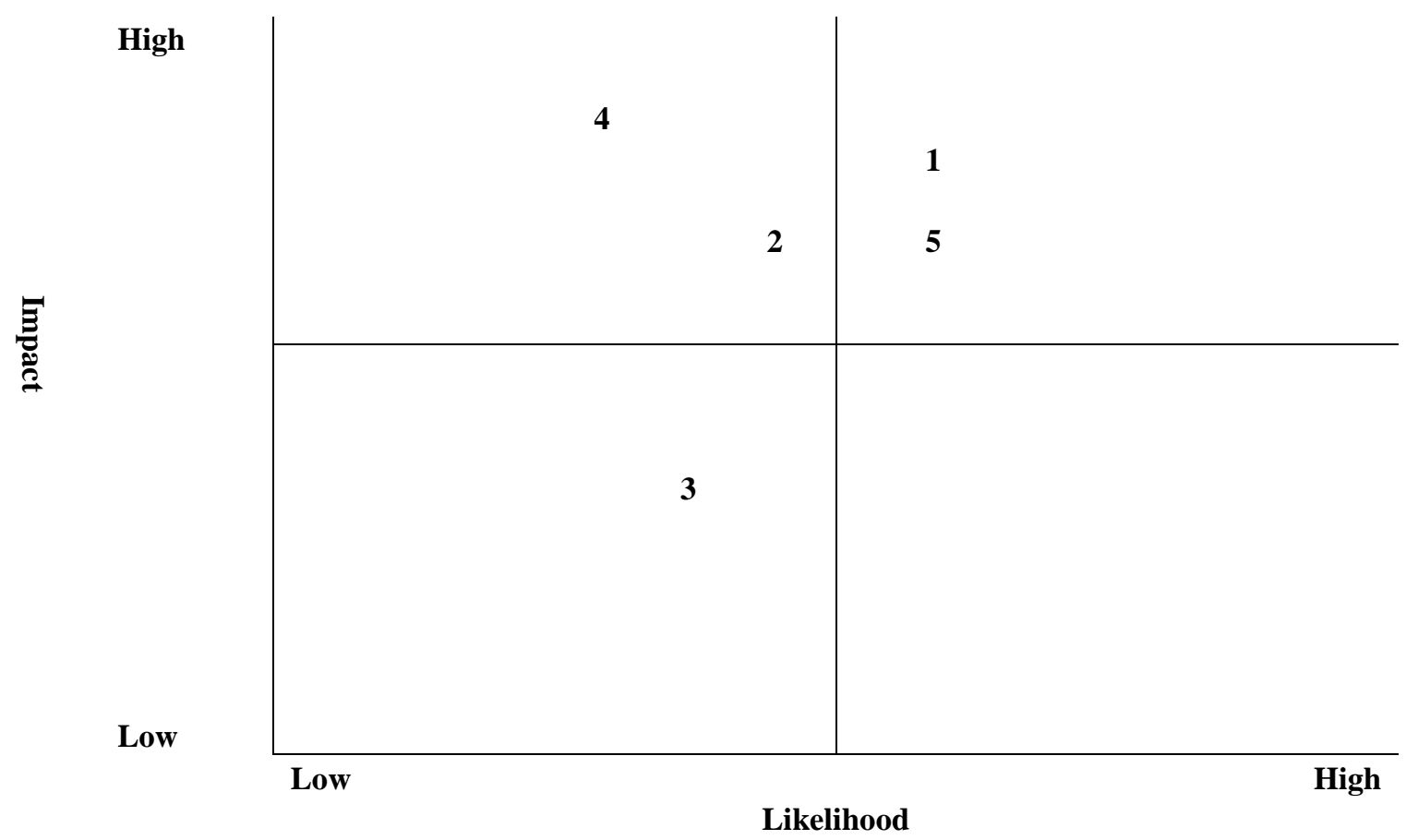

Strategic Risk Factors:

1. Poor attendance from competitors due to insufficient prizes

2. Lack of publicity for tournament/gathering sufficient spectator interest

3. Expenses exceeding revenues

4. Competitors being under the influence of drugs or alcohol

5. Bad publicity for not being environmentally friendly 


\section{Operational Risk Map}

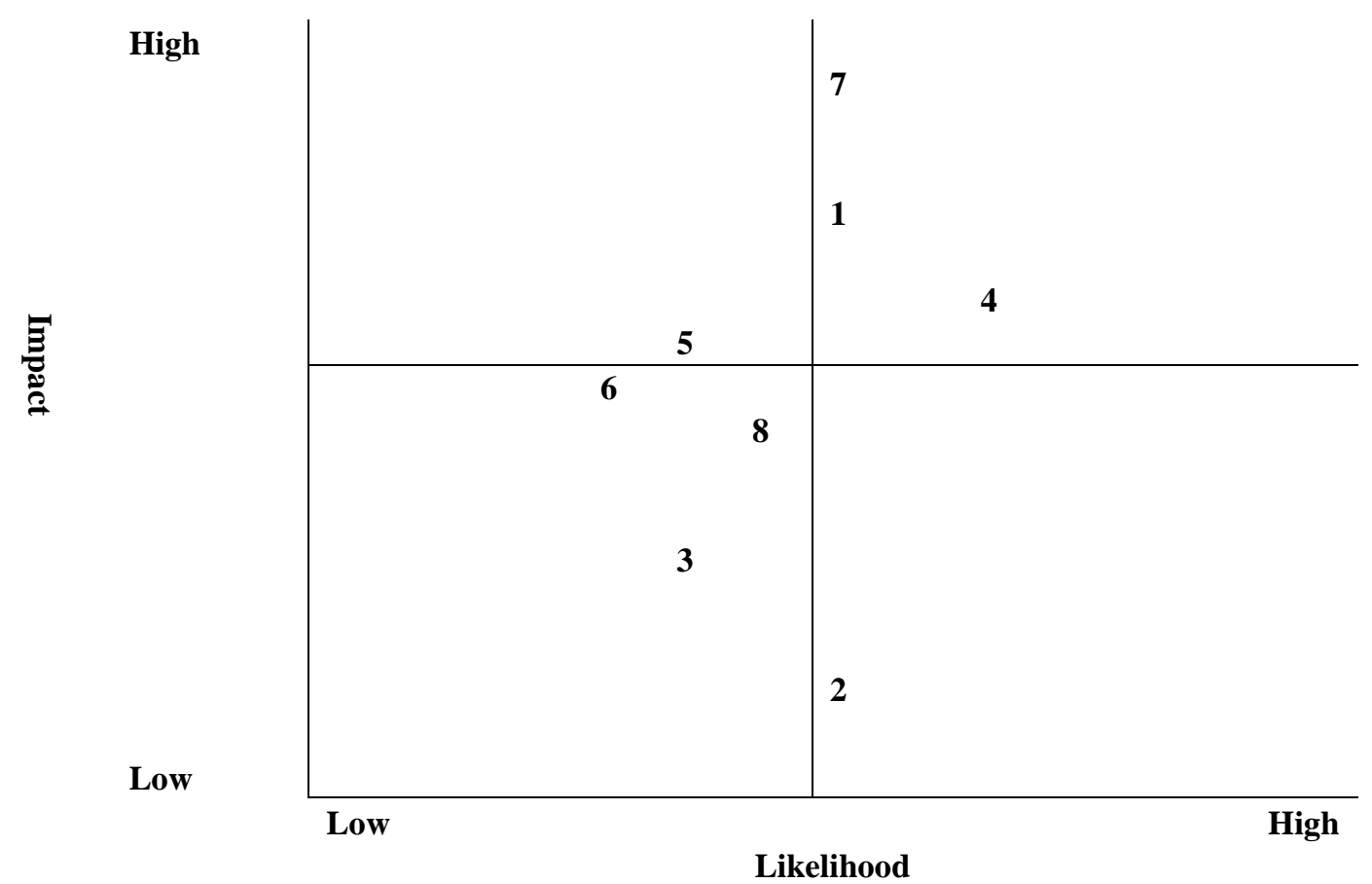

Operational Risk Factors:

1. Cheating or other misconduct by competitors or spectators

2. Problems with registration of competitors or other administrative tasks

3. Inclement weather or poor fishing conditions (e.g., muddy water, red tide, overcrowding)

4. Equipment inaccuracies or malfunction

5. Failure of staff to properly carry out responsibilities; Weak administration of tournament and/or incompetent/corrupt tournament director

6. Advance knowledge of the tournament venue

7. Boating accidents

8. Competitors having an unpleasant experience 


\section{Compliance Risk Map}

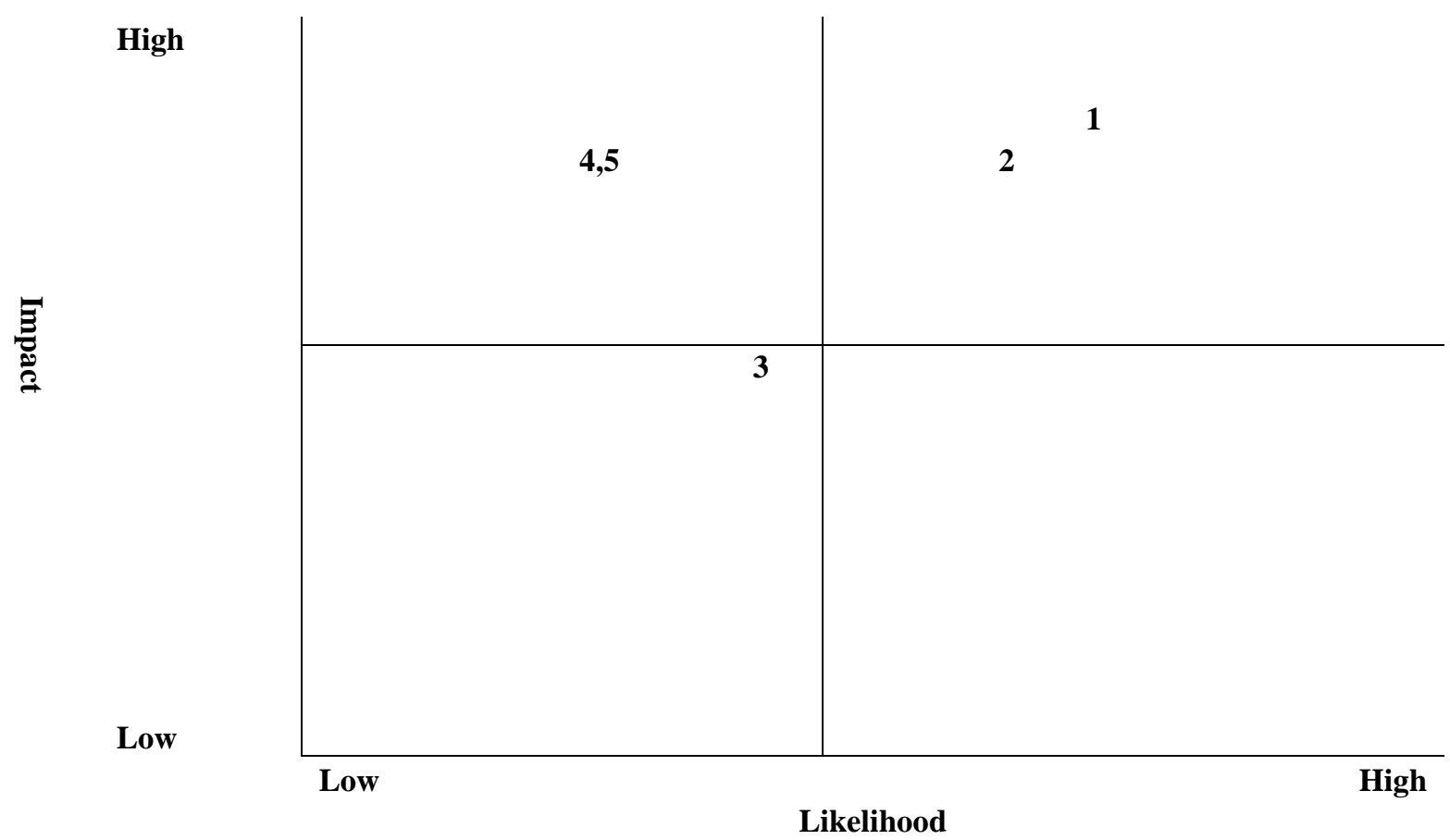

Compliance Risk Factors:

1. Noncompliance with State and federal gaming laws/regulations

2. Improper reporting to the IRS and state taxing authorities on winners' boot

3. Noncompliance with Federal Trade Commission regulations (if broadcasted)

4. Disregard for demands from activist organizations (e.g., PETA)

5. Insensitivity to other environmental issues 


\section{Reporting Risk Map}

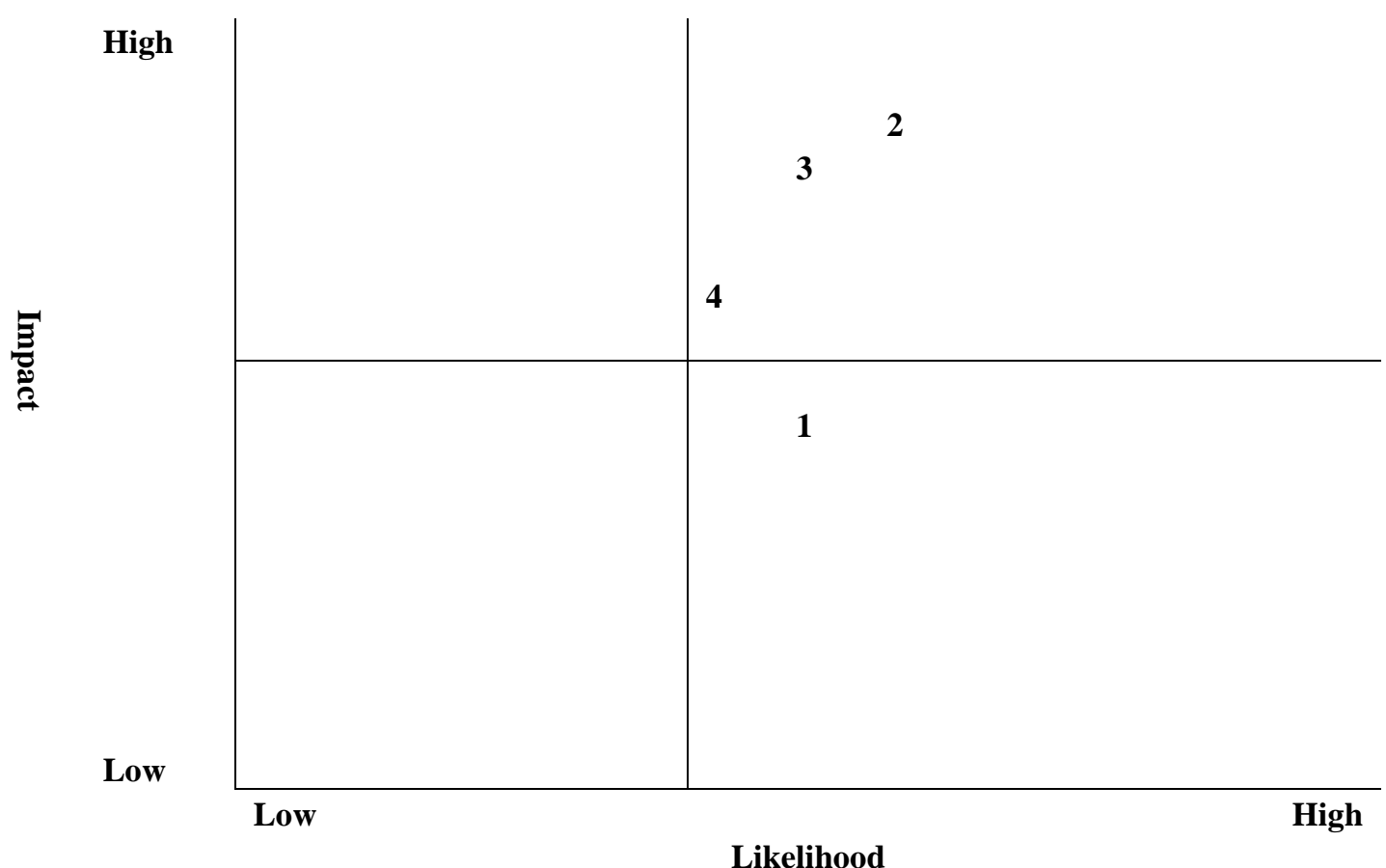
Reporting Risk Factors:
1. Inaccurate reporting to state wildlife authorities
2. Inaccurate tax reporting of winners and the promoters
3. Inaccurate announcements/communications at the tournament
4. Failure to provide appropriate internal reporting

\section{BIOGRAPHIES}

George L. Hunt Ph.D., CPA, CIA, CMA holds an undergraduate degree from Texas A\&M University, a Masters of Accountancy from Texas State University, and a Ph.D. in Business Administration from Texas Tech University. His research interests include taxation, internal auditing, risk management, and governmental accounting. He has published articles in the Internal Auditor, Today's CPA, and the Journal of Economics and Business.

Jack R. Ethridge Ph.D., CPA is the Temple-Inland Employees Distinguished Professor of Accounting in the Gerald W. Schlief School of Accountancy at Stephen F. Austin State University in Nacogdoches, TX. He received his PhD. from the University of Arkansas in 1986. His areas of interest are auditing and financial. Dr. Ethridge's articles have been published in a variety of journals.

Violet C. Rogers Ph.D., CPA is a Professor of Accountancy at Stephen F. Austin State University. She received her $\mathrm{PhD}$ from the University of North Texas in 1993 and joined the faculty at SFA in 1991. She teaches Auditing, Accounting Regulation, and Managerial Principals. Dr. Rogers' articles have been published in a variety of academic Journals. 


\section{BIBLIOGRAPHY AND FURTHER READINGS}

\section{Books}

1. Boyle, Robert H., Bass Boss: the Inspiring Story of Ray Scott and the Sport Fishing Industry He Created, Pintlala, AL: Whitetail Trail Press, 1999.

\section{Popular Media}

1. $\quad$ Anderson, Chris, "Fishin' for a Livin'," Sarasota Herald Tribune, Dec. 15, 2007.

2. $\quad$ AP, "Judge Sentences 4 to Prison for Fishing Contest Cheating," New York Times, April 6, 1985.

3. Ballard, Chris, "Kickin' Some Bass!” Sports Illustrated, December 5, 2005.

4. Bernarde, Scott, "Bass Tournaments: Hooking Fish for Big Dough," Atlanta Journal-Constitution, February 15, 2008.

5. Doggett, Joe, "It's Easy to Develop a Taste for Tournaments," Houston Chronicle, July 29, 1999.

6. Duncan, Heather, "Luring in the Big One: State Hopes 'Go Fish Georgia' Initiative Will Attract Bass Tournaments While Improving Fishing," Macon Telegraph, March 15, 2007.

7. $\quad$ Figura, David, “Anglers Reel in One Too Many,” Post Standard, August 15, 2009.

8. Godfrey, Ed, "What Happens When Fish Stories Become Fraud?" Daily Oklahoman, June 22, 2007.

9. Graves, Lee, “Anglers Don't Get Off Hook, Claiming Ignorance of the Rules," Richmond Times Dispatch, April 19, 2006.

10. Graves, Lee, "Morris Fighting Recent DQ," Richmond Times Dispatch, June 17, 2007.

11. Hart, Tim, "There's Something Fishy about These Ethics," Canberra Times, August 8, 2010.

12. Hayes, John, "The Biggest Fish," Pittsburg Post-Gazette, July 29, 2009.

13. Huggins, Paul, "Fishing for Dollars with Wheeler as the Bait: 9 Tournaments in 12 Months Have $\$ 1.5$ Million Economic Impact on River City; Hotel Owners are Smiling," Decatur Daily, October 19, 2007.

14. Lamb, Bob, "When Fishing Tournaments Come to Town, Money Follows," La Crosse Tribune, July 23, 2006.

15. Lidz, Franz, “Gone Cheating," Sports Illustrated, Vol. 97, Issue 9, p.31.

16. Mosby, Joe, "It Took Time for Classic to Gain Momentum," ESPNOutdoors.com, February 1, 2007.

17. Mueller, Gene, "Angler Rocks the Boat with Temper Tantrum," Washington Times, March 8, 2006.

18. Mueller, Gene, "Tackling a New Method," Washington Times, September 13, 2009.

19. Nelson, Dick, "B.A.S.S. Rules Eliminate Cheaters," Albany Times Union, July 23, 1989.

20. Nielson, C. Douglas, "Breach of Integrity Costly for Fisherman," Las Vegas Review-Journal, July 29, 2010.

21. Sandomir, Richard, “'Bassinine Error' Mars Tournament,” New York Times, November 8, 1999.

22. Sasser, Ray, "Big Money Will Always Be a Lure for Cheaters in Fishing Tournaments," Dallas Morning News, April 21, 2010.

23. Scott, Ray, "Zero Tolerance," www.bassfan.com, March 30, 2004.

24. Staff Writer, "Lie Detector Separates Fish Stories from Reality," Winnipeg Free Press, July 24, 2009.

25. Staff Writer, "Shortcuts," Star, April 27, 2010.

26. States News Service, "Game Warden Probe Nets Guilty Plea in Bass Tournament." States News Service, April 14, 2010.

27. Stodghill, Ron II, "Just Call it BassCar: Professional Fishing League," Time, September 3, 2001.

28. Sports Column, "B.A.S.S. Founder Scott Leaves Mark on Fishing Industry," Tampa Tribune, February 22, 2002.

29. $\quad$ Sports Section, “Talking Points," Albany Times Union, August 7, 2010.

30. Taylor, Mark, "Big Prize Money Spawns Abuses," Roanoke Times, April 4, 2006.

31. Taylor, Mark, "Fish Stories," Roanoke Times. May 2, 2008.

32. Taylor, Mark, "Fishing Tourney Cheaters Never Win," Roanoke Times, June 8, 2008.

33. Taylor, Mark, "Catfish, Crappie Leader Disqualified," Roanoke Times, May 3, 2010.

34. Taylor, Mark, "Disqualification Costs Angler \$2,000," Roanoke Times, May 7, 2010.

35. Taylor, Mark, "Fishing Stories Sometimes Just Too Fishy," Roanoke Times, May 9, 2010.

36. Tolliver, Lee, "Beach Pro Seeks to Have Disqualification Reversed," Virginia-Pilot, June 17, 2007. 
37. Tolliver, Lee, “\$1.2 Million at Stake as Tourney Results are Placed on Hold,"”Virginia-Pilot, June 22, 2010.

38. Tolliver, Lee, "Fishermen Tales Put to the Test," Virginia-Pilot, August 17, 2010.

39. Tolliver, Lee, "Even Honest Anglers Can Feel Pressure from Polygraphs," Virginia-Pilot, August 17, 2010.

40. UPI, "Fishing Cheater: I Wasn't Trying to Win," UPI Quirks in the News, April 15, 2010.

41. Weisberg, Deborah, "Bass Must Arrive Alive," Pittsburgh Post-Gazette, July 30, 2005.

42. Whitney, Joel, "Just When You Thought it Was Safe...," New York, June 19, 2006.

43. Williams, Matt, "Tournaments Cheats and the Law," Texas Fish and Game, August 2010, p. 38.

44. Wray, Quentin, "Fly-fishing: Something Fishy," Financial Times Limited, March 6, 2009.

45. Zieralski, Ed, "Local Tournaments on Lookout for Bass Cheats," San Diego Union-Tribune, July 27, 2010.

\section{Court Cases}

1. $\quad$ Fla.App.1976.

State v. Oates

330 So. $2 \mathrm{~d} 554$

2. $\quad$ S.C. App., 1985, Ahrens v. McDaniel

287 S.C. 63,336 S.E. $2 d 505$

3. Tex.App.-Texarkana, 1990

Lynd v.State

784 S.W.2d 480

4. Wis.App, 1987

Schmidt v. Three Lakes Chamber of Commerce

142 Wis.2d 936, 417 N.W.2d 196

\section{Professional Literature}

1. ESPN Outdoor Bassmaster Series Official Rules, Effective January 1, 2006.

2. Committee of Sponsoring Organizations of the Treadway Commission (COSO), Enterprise Risk Management-Integrated Framework: Application Techniques, AICPA, New York, 2004.

3. COSO, Enterprise Risk Management-Integrated Framework: Executive Summary, AICPA, New York, 2004.

4. Canadian Institute of Chartered Accountants (CoCo), Guidance on Control, Institute of Chartered Accountants, Canada, 1995.

5. Financial Reporting Council, Internal Control: Revised Guide for Directors on the Combined Code (Turnbull), Financial Reporting Council, 2005.

6. Institute of Internal Auditors, the American Institute of Certified Public Accountants, and Association of Certified Fraud Examiners, Managing the Business Risk of Fraud: A Practical Guide. Available for download at www.theiia.org.

7. Institute of Management Accountants, Statement on Management Accounting: Enterprise Risk Management: Frameworks, Elements, and Integration, Institute of Management Accountants, New Jersey, 2006.

8. Institute of Management Accountants, Statement on Management Accounting: Enterprise Risk Management: Tools and Techniques for Effective Implementation, Institute of Management Accountants, New Jersey, 2007.

9. The Institute of Internal Auditors. Internal Auditing: Assurance \& Consulting Services, $2^{\text {nd }}$ Ed., 2009. 


\section{Academic Research}

1. Edwards, Gordon P., Jr., Robert M. Neumann, Robert P. Jacobs, and Eileen B. O'Donnell, Impacts of Small Club Tournaments on Black Bass Populations in Connecticut and the Effects of Regulation Exemptions, North American Journal of Fisheries Management, 204, 24:3, pp. 811-821.

2. Lommis, David K. and Robert B. Ditton, Analysis of Motive and Participation Differences between Saltwater Sport and Tournament Fishermen, North American Journal of Fisheries Management, 1987, 7 , pp. $482-487$.

3. Oh, Chi-Ok, Robert B. Ditton, and Robin Riechers, Understanding Anglers' Preferences for Fishing Tournament Characteristics and Policies, Environmental Management, 2007, 40:1, pp. 123-133.

4. Ostrand, Kenneth G., Gene R. Wilde, Dan W. Strickland, and Maurice I. Muoneke, Initial Mortality in Texas Black Bass Fishing Tournaments, North American Journal of Fisheries Management, 1999, 19:4, pp. 1124-1128.

5. Schramm, Harold L., Aaron R. Walters, John M. Gizzle, Benjamin H. Beck, Larry A Hanson, and Steven B. Rees, Effects of Live-Well Conditions on Mortality and Largemouth Bass Virus Prevalence in Largemouth Bass Caught during Summer Tournaments, North American Journal of Fisheries Management, 2006, 26:4, pp. 812-825.

6. Schramm, H.L. and P.H. Gerard, Temporal Changes in Fishing Motivation among Fishing Club Anglers in the United States, Fisheries Management and Ecology, 2004, 11:5, p. 313-321.

7. Schramm, H.L. and K.M. Hunt, Issues, Benefits, and Problems Associated with Fishing Tournaments in Inland Waters of the United States: A Survey of Fishery Agency Administrators. Fisheries, 2007, 32, p. 234-243.

8. Wilde, Gene R., Robin K. Riechers, and Robert B. Ditton, Differences in Attitudes, Fishing Motives, and Demographic Characteristics between Tournament and Nontournament Black Bass Anglers in Texas, North American Journal of Fisheries Management, 1998, 18:2, pp. 422-431.

9. Wilde, Gene R., Dan W. Strickland, Kenneth G. Ostrand, and Maurice I. Muoneke, Characteristics of Texas Black Bass Fishing Tournaments, North American Journal of Fisheries Management, 1998, 18:4, pp. 972-977.

10. Wilde, Gene R., Calub E. Shavlik, and Kevin L. Pope, Initial Mortality of Black Bass in B.A.S.S. Fishing Tournaments, North American Journal of Fisheries Management, 2002, 22:3, pp. 950-954.

11. Yee, Thomas W., "Some Issues Raised by an Analysis of the 2008 World Fly Fishing Championship Data. Dept. of Statistics, University of Auckland, New Zealand.

\section{Other}

1. Official Bassmaster Weekend Circuit Rules, Waiver Form, and Registration Forms can be downloaded at: http://sports.espn.go.com/outdoors/bassmaster/bmseries/news/story?page=b_news_weekend_rules_04

2. $\quad$ www.bassmaster.com

3. www.espn.com 
Journal of Business Case Studies - July/August 2011 Volume 7, Number 4

NOTES 